\title{
Increase in the resistance to the Bacillus thuringiensis supernatant effect in a Drosophila melanogaster wild type Oregon $R$ line
}

\author{
SOLANGE PAUMARD-RIGAL* \& MYRIAM ROSENBERG-BOURGIN \\ Institut Jacques Monod, Université Paris 7-2, Place Jussieu 75251 Paris Cedex 05, France
}

\begin{abstract}
We report here the genetical and X chromosome rDNA molecular study of two Drosophila melanogaster Oregon $\mathrm{R}$ lines. These lines differ extensively in the degree of resistance of the females both to the lethal effect of an increased temperature and to that of Bacillus thuringiensis beta-exotoxin, which is an inhibitor of the nucleolar RNA polymerase. The $3 \mathrm{~B}$ line, whose females are resistant, came from an Oregon $\mathrm{R}$ population subjected over several generations to increased temperature, $28^{\circ} \mathrm{C}$ or over, while the other line is derived from the initial stock. Twofold variation was observed in the total number of ribosomal genes between the two lines. This variation applied to most ribosomal units, including the active ones. Variations among $\mathrm{X}$ chromosome rDNA content in a wild type population have thus been revealed using tests of resistance to the Bacillus thuringiensis beta-exotoxin. Additive variations in specific unit types between the two lines indicate that modifications to the rDNA content are not rare events.
\end{abstract}

Keywords: Bacillus thuringiensis, beta-exotoxin, Drosophila melanogaster, evolution, high temperature lethality, rDNA.

\section{Introduction}

The ribosomal DNA, located at the nucleolar organizer sites of the chromosomes, is composed of the genes for the 28S, $18 \mathrm{~S}$ and $5.8 \mathrm{~S}$ type RNA, clustered as repeated transcriptional units. In the Drosophila melanogaster species, the nucleolar organizers are on the heterochromosomes (Cooper, 1959; Ritossa \& Spiegelman, 1965; Spear, 1974). Many ribosomal units of the $\mathrm{X}$ chromosome are interrupted by an insertion into the 28S gene sequence (Long \& Dawid, 1980). Two classes of non-homologous insertions have been identified named type I, largely represented, and type II (Roiha et al., 1981). Only the uninterrupted units seem to be transcriptionally active (Long \& Dawid, 1979; Long et al., 1980; Kidd \& Glover, 1981; Terracol \& Prud'homme, 1986). Compared to the X chromosome, interrupted units are in a smaller proportion on the $Y$ chromosome where only type II insertions have been

*Correspondence: Solange Paumard-Rigal, Laboratoire de Génétique quantitative et moléculaire, tour 42-32, 5ème étage, Institut Jacques Monod, Université Paris 7-2, Place Jussieu 75251Paris Cedex 05, France. identified (Tartof \& Dawid, 1976; Wellauer et al., 1978; Peacock et al., 1981).

The supernatant of cultures of the Bacillus thuringiensis Berliner strain contains a thermostable toxin (McConnel \& Richards, 1959): the beta-exotoxin or thuringiensin, which acts in vivo as a preferential inhibitor of nucleolar RNA polymerase (Mackedonski et al., 1972; Beebee \& Bond, 1973). Like the purified toxin, the supernatant has a lethal effect during the development stage if added to the nutritional medium (Paumard \& Bourgin-Rosenberg, 1981). Using 'bobbed' mutants, we have previously shown that lethality increases when the ribosomal DNA amount decreases (Paumard \& Bourgin-Rosenberg, 1981). In Oregon $\mathbf{R}$ populations, the males are more resistant than females to the lethal effect of the supernatant; this has been correlated with a greater number of uninterrupted units on the $\mathrm{Y}$ chromosome compared to the $\mathrm{X}$ chromosome (Rosenberg-Bourgin et al., 1988b).

The amount of ribosomal DNA on the two chromosomes and the proportion of the different classes of uninterrupted and interrupted units can vary between different strains of Drosophila melanogaster and even 
between lines originated from the same strain (Endow \& Glover, 1979; Dutton \& Kricler, 1984; RosenbergBourgin et al., 1988a).

From an Oregon $\mathrm{R}$ stock bred for several generations at temperatures which often reach and sometimes exceed $28^{\circ} \mathrm{C}$, we have spontaneously obtained a variant population in which the females are more resistant to the lethal effect of the supernatant than those of the initial stock. The initial and variant Oregon $\mathrm{R}$ populations do not exhibit any difference on a standard medium at $25^{\circ} \mathrm{C}$. However, these two populations express differences when they are bred at $28^{\circ} \mathrm{C}$ : this temperature has a lethal effect during development and females of the variant population are more resistant than those of the initial population; we have shown that genotypes resistant to increased temperature were present in the initial stock and have been positively selected when bred at the high temperature (Paumard-Rigal \& Rosenberg-Bourgin, 1990). We have postulated that variation in the degree of resistance to Bacillus thuringiensis supernatant could reveal variations in the amount of active rDNA units. By successive individual crosses, two lines, whose females differ extensively for resistance to beta-exotoxin, have been isolated: the $3 \mathrm{~B}$ line from the variant population and the $1 \mathrm{C}$ line from the initial one (Paumard-Rigal \& Rosenberg-Bourgin, 1990). We report here on the results of genetical and molecular studies of these two Oregon $\mathrm{R}$ lines.

\section{Materials and methods}

\section{Drosophila melanogaster stocks}

The $1 \mathrm{C}$ line and $3 \mathrm{~B}$ line came from the Oregon $\mathrm{R}$ stock of the Centre de Génétique Moléculaire of Gif sur Yvette (France). The '94' strain originated from the collection of the Centre de Génétique Moléculaire of Gif sur Yvette (France). The females C1 (RM) have two attached $\mathrm{X}$ chromosomes and no $\mathrm{Y}$ chromsome (Lindsley \& Grell, 1968).

Drosophila stocks were grown on cornmeal yeast extract agar medium. $(75 \mathrm{~g}$ cornmeal, $75 \mathrm{~g}$ yeastextract, $125 \mathrm{~g}$ agar-agar and $45 \mathrm{ml}$ of a $10 \mathrm{~g} / 100 \mathrm{ml}$ solution of methyl- $p$-hydroxybenzoate in 90 per cent alcohol for 1 litre of medium).

\section{Evaluation of the effect of the Bacillus thuringiensis thermostable supernatant}

Drosophila were grown at $25^{\circ} \mathrm{C}$. Supernatant from a culture of Bacillus thuringiensis Berliner strain harvested at the end of sporulation was autoclaved for 20 min at $120^{\circ} \mathrm{C}$ and added to the standard medium at a final concentration of 1.5 or 2.5 per cent (vol./vol.). The Bacillus thuringiensis cultures were grown at $30^{\circ} \mathrm{C}$ using the conditions described in Lecadet \& Dedonder (1971). The supernatant effect was assayed by counting the adults emerging after all their development had taken place on a supplemented supernatant medium, from eggs laid on this medium over 4 days by 12 females mated with 12 males. The same batch of bacterial culture supernant was used for all experiments.

\section{Extraction of brain DNA from third-instar larvae}

Brains and imaginal discs of about 30 third-instar female larvae were dissected in Drosophila Ringer solution (Ephrussi \& Beadle, 1936). After the addition of $7 \mu \mathrm{l}$ of a $2 \mathrm{mg} \mu \mathrm{l}^{-1}$ solution of self-digested pronase, they were incubated for $22-24 \mathrm{~h}$ at room temperature under slow agitation in an Eppendorf tube, in $250 \mu \mathrm{l}$ of $50 \mathrm{~mm}$ Tris $\mathrm{HCl} \mathrm{pH} \mathrm{7.8,} 100 \mathrm{~mm}$ EDTA and 0.5 per cent SDS. After incubation, $250 \mu \mathrm{l} \mathrm{NaCl} 2 \mathrm{M}$ and 500 $\mu \mathrm{l}$ of chloroform-isoamyl alcohol $(24: 1)$ were added successively. The preparation was gently mixed for $3 \mathrm{~min}$, kept for $10 \mathrm{~min}$ at $0^{\circ} \mathrm{C}$ and then centrifuged for $5 \mathrm{~min}$ at $12,000 \mathrm{~g}$. Two microlitres of $10 \mathrm{mg} \mathrm{ml}^{-1}$ RNAse A were added to the supernatant and was incubated for $2 \mathrm{~h}$ at $37^{\circ} \mathrm{C}$. After a second treatment with chloroform-isoamyl alcohol, the DNA was precipitated for $15 \mathrm{~min}$ at $-70^{\circ} \mathrm{C}$ by the addition of $1 \mathrm{ml}$ ethanol and was dissolved in $30 \mu 1 \mathrm{TE}(10 \mathrm{~mm}$ Tris-HCl pH 8, 1 mм EDTA) after centrifugation and drying.

\section{The $p D m r Y_{12}$ plasmid}

The $\mathrm{pDmrY}_{12}$ plasmid, isolated by the method of Birnboim \& Doly (1979), contains an 11.7 kb EcoRI insribosomal DmrY 12 fragment in the EcoRI site of ColEI (Wellauer et al., 1978).

\section{DNA electrophoresis, transfer and hybridization}

Electrophoresis was performed in $\mathrm{pH} 8$ borate buffer $(89 \mathrm{~mm}$ Tris base, $89 \mathrm{~mm}$ boric acid, $2 \mathrm{~mm}$ EDTA $\mathrm{pH} 8$ ) with the addition of $1 \mu \mathrm{g} \mathrm{ml}^{-1}$ of ethidium bromide. After electrophoresis, the agarose gels were treated successively, twice for $15 \mathrm{~min}$ with $0.25 \mathrm{M} \mathrm{HCl}$, twice for $15 \mathrm{~min}$ with $0.5 \mathrm{M} \mathrm{NaOH}, 1.5 \mathrm{M} \mathrm{NaCl}$, and twice for $30 \mathrm{~min}$ with $0.02 \mathrm{M} \mathrm{NaOH}, 1 \mathrm{M}$ ammonium acetate. Transfer to a Schleicher and Schüll BA 85 nitrocellulose filter was carried out in $0.02 \mathrm{M} \mathrm{NaOH}$, $1 \mathrm{~m}$ ammonium acetate for 10-12 h. DNA was fixed to the membrane by heating for $2 \mathrm{~h}$ at $80^{\circ} \mathrm{C}$. Filters were prehybridized at $42^{\circ} \mathrm{C}$ for $2 \mathrm{~h}$ in the following mixture 
(Wahl et al., 1979): 50 per cent formamide- $5 \times$ SSC ( $1 \times \mathrm{SSC}$ is $150 \mathrm{~mm} \mathrm{NaCl}, 15 \mathrm{~mm}$ sodium citrate), $5 \times$ Denhardt solution $(1 \times$ Denhardt is 0.02 per cent polyvinylpyrrolidone, 0.02 per cent ficoll, 0.02 per cent bovine serum albumin), $50 \mathrm{~mm}$ sodium phosphate buffer ( $\mathrm{pH}$ 7.4), 1 per cent SDS. The filters were then hybridized at $42^{\circ} \mathrm{C}$ for $20-24 \mathrm{~h}$ in 50 per cent formamide $5 \times$ SSC, $1 \times$ Denhardt solution, $20 \mathrm{~mm}$ sodium phosphate buffer ( $\mathrm{pH} 7.4), 6$ per cent dextransulfate 500,1 per cent SDS, $100 \mu \mathrm{g} \mathrm{ml}^{-1}$ of yeast tRNA, $2 \mathrm{ng} \mathrm{ml}{ }^{-1}{ }^{32} \mathrm{P}$-nick-translated $\mathrm{pDmrY}_{12}$ or $\mathrm{DmrY}_{12}$ $\left(0.5-1 \times 10^{8} \mathrm{cpm} \mu \mathrm{g}^{-1}\right)$ denatured for $10 \mathrm{~min}$ at $100^{\circ} \mathrm{C}$. The filters were rinsed successively once at room temperature for $5 \mathrm{~min}$ in $2 \times \mathrm{SSC}$, three times at $42^{\circ} \mathrm{C}$ for $20 \mathrm{~min}$ in $2 \times \mathrm{SSC}-1$ per cent SDS, twice at $42^{\circ} \mathrm{C}$ for $20 \mathrm{~min}$ in $0.5 \times \mathrm{SSC}-0.1$ per cent SDS. Filters were exposed to Kodak X-Omat $\mathrm{R}$ films for different times (in general $1-72 \mathrm{~h}$ ). Autoradiographs were scanned on a Shimadzu CS 930 densitometer. The areas were determined with several autoradiographs within the linear response range of the film.

\section{Ribosomal DNA quantification}

The number of ribosomal units per $\mathrm{X}$ chromsome was determined after loading of Drosophila DNA samples on a 1 per cent agarose minigel containing ethidium bromide. The quantity of total Drosophila DNA in each slot was first evaluated: known quantities of lambda DNA were loaded on the same minigel and, after a short migration, the fluorescence intensity, under ultraviolet light, of the different samples of Drosophila DNA was compared with that of the standards. The fluorescence intensity of each sample was determined precisely after scanning the photographic negatives. The number of haploid genomes (i.e. the same as the number of $\mathrm{X}$ chromosomes in the females) was calculated with the knowledge that the haploid genome contains $0.18 \mathrm{pg}$ DNA.

The number of ribosomal units on each Drosophila DNA sample was determined by loading known quantities of $\mathrm{pDmr} \mathrm{Y}_{12}$ added to $250 \mathrm{ng}$ of calf thymus DNA in the slots where the lambda DNA had first been loaded. After a short electrophoresis, the DNA was transferred to nitrocellulose filters and hybridized with ${ }^{32} \mathrm{P} D_{D m r Y}$. The hybridization signals of the various Drosophila DNA samples were compared with those of the standards. The signal intensity was precisely determined after scanning the autoradiographs. The determination of the number of ribosomal units was realized by taking into account the fact that the Drosophila insert DmrY $\mathrm{Y}_{12}$ (representing 67 per cent of the total $\mathrm{pDmrY}_{12}$ plasmid and corresponding to a $11.7 \mathrm{~kb}$ uninterrupted unit) is equivalent to
$1.52 \times 10^{-5} \mathrm{pg}$ of DNA. The method is illustrated in Rosenberg-Bourgin et al. (1988a).

The ratio between the number of ribosomal units and the number of haploid genomes was calculated for at least three independent DNA samples to determine the number of ribosomal units per $\mathrm{X}$ chromosome.

\section{Distribution of the different ribosomal unit types}

The extracted Drosophila DNA was diluted in a final volume of $45 \mu \mathrm{l}$ in a buffer of the following composition: $5 \mathrm{mM} \mathrm{MgCl} 2,100 \mathrm{mM}$ Tris- $\mathrm{HCl} \mathrm{pH} \mathrm{7.5,50} \mathrm{mM}$ $\mathrm{NaCl}, 100 \mathrm{ng} \mu \mathrm{l}^{-1}$ of bovine serum albumin. Lambda DNA $(4.5 \mu \mathrm{g})$ was added in order to test the complete enzymatic digestion and to be used as a size marker in the autoradiographs. The DNA preparation was treated with EcoRI. Agarose gels (0.6 per cent) were loaded with $11 \mu \mathrm{l}$ of the DNA digests obtained from 20 brains for the $3 \mathrm{~B}$ line and 40 brains for the $1 \mathrm{C}$ line with the BRL size market ' $1 \mathrm{~kb}$ ladder', which gives rise to numerous fragments from 3 to $12 \mathrm{~kb}$. After electrophoresis at $110 \mathrm{~V}$ for $15-20 \mathrm{~h}$, transfer, and hybridization, the resulting autoradiographs were scanned to determine the percentage of the different size fragments.

\section{Results}

\section{Genetical results}

The characterization of the two Oregon $\mathrm{R}$ lines, 3B and $1 \mathrm{C}$, in the presence of the 2.5 per cent supernatant is shown in Table 1 . For the $1 \mathrm{C}$ line, the male/female sex ratio is increased in the presence of 2.5 per cent Bacillus thuringiensis supernatant: 1.1 without supernatant to 6.2 in the presence of the inhibitor. For the $3 \mathrm{~B}$ line, there is no difference in the sex ratio value: 1.0 and 1.07. The difference in the sex ratio between these lines in the presence of 2.5 per cent supernatant is due to an increase in the resistance of $3 \mathrm{~B}$ line females compared to the ones in line $1 \mathrm{C}$.

We have compared the resistance of the homozygous $3 \mathrm{~B}$ and $1 \mathrm{C}$ females to the resistance of the females heterozygous for the two genotypes, obtained in the reciprocal crosses between the $3 \mathrm{~B}$ females and the $1 \mathrm{C}$ males or between $1 \mathrm{C}$ females and $3 \mathrm{~B}$ males (Table 1). The male/female sex ratio is the same for the two crosses: respectively 2.04 and 2.0 ; this value lies between the value obtained for the $1 \mathrm{C}$ line and that obtained for the $3 \mathrm{~B}$ line. The number of males is similar in each case, so females that have a heterozygous genotype $3 \mathrm{~B} / 1 \mathrm{C}$ have a similar resistance in both reciprocal crosses. 
Table 2 shows the influence of the nature of the $\mathrm{X}$ chromosome and the nature of the autosomes on the resistance of $\mathrm{X} / \mathrm{O}$ males generated from crosses between X.X females of the '94' strain and males of different genotypes. In these crosses, the $\mathrm{X} / \mathrm{O}$ males receive the $\mathrm{X}$ chromosome from their father. There is no difference in the progeny of these different crosses in the standard medium and whatever may be the father's genotype, no X/O male exhibits a bobbed phenotype. In the presence of 2.5 per cent supernatant, $\mathrm{X} / \mathrm{O}$ males generated by males with a heterozygous autosomal stock $3 \mathrm{~B} / 1 \mathrm{C}$ and the $3 \mathrm{~B} \mathrm{X}$ chromosome are very resistant (sex ratio 0.56 ) compared to $\mathrm{X} / \mathrm{O}$ males generated by males with the same autosomal stock but with the $1 \mathrm{CX}$ chromosome (sex ratio 0.08 ). The resistance of $\mathrm{X} / \mathrm{O}$ males was similar when a different autosomal stock was used, sex ratios of 0.67 and 0.56 for the males with the $3 \mathrm{~B} \mathrm{X}$ chromosome and 0.06 and 0.08 for the males with the $1 \mathrm{C} \mathrm{X}$ chromosome.

Thus neither the nature of the autosomes nor any cytoplasmic heredity are involved in the difference in resistance between the two lines. This difference is only correlated with a difference between the $\mathrm{X}$ chromosomes of these lines.

\section{Molecular results}

The number of ribosomal units per $\mathrm{X}$ chromosome for the $3 B$ and $1 C$ Oregon $R$ lines is $418 \pm 10.6$ and $195 \pm 13.3$ respectively, representing a twofold difference.

The EcoRI X chromosome ribosomal DNA restriction patterns of the two lines are presented in Fig. 1. The results of densitometric scannings are reported in

Table 1 Comparison of the effect of 2.5 per cent Bacillus thuringiensis supernatant at $25^{\circ} \mathrm{C}$ on the sex ratio, for the progeny of the two Oregon $\mathrm{R}$ lines $1 \mathrm{C}$ and $3 \mathrm{~B}$ and for that of the reciprocal crosses, between these two lines

\begin{tabular}{|c|c|c|c|c|c|c|}
\hline \multirow[b]{2}{*}{ Parents } & \multicolumn{2}{|c|}{$\begin{array}{l}\mathrm{X} / \mathrm{Y} \text { males } \\
\text { per flask }\end{array}$} & \multicolumn{2}{|c|}{$\begin{array}{l}\mathrm{X} / \mathrm{X} \text { females } \\
\text { per flask }\end{array}$} & \multicolumn{2}{|c|}{$\begin{array}{l}\text { Male/female } \\
\text { ratio }\end{array}$} \\
\hline & $S+$ & $S-$ & $S+$ & $S-$ & $S+$ & $S-$ \\
\hline $1 C^{*}$ line & 259 & (232) & 42 & $(211)$ & 6.2 & $(1.1)$ \\
\hline $3 \mathrm{~B} \dagger$ line & 275 & (238) & 257 & $(237)$ & 1.07 & (1) \\
\hline $3 \mathrm{~B}$ females $\times 1 \mathrm{C}$ males & 233 & (233) & 114 & $(225)$ & 2.04 & $(1.04)$ \\
\hline $1 \mathrm{C}$ females $\times 3 \mathrm{~B}$ males & 241 & (228) & 120 & (228) & 2 & (1) \\
\hline
\end{tabular}

$\mathrm{S}+=$ with 2.5 per cent supernatant, $\mathrm{S}-=$ without supernatant.

$\mathrm{S}+$ and $\mathrm{S}-$ values are means of at least five flasks.

*Line originated from the initial Oregon $\mathrm{R}$ population.

$\nmid$ Line originated from the variant Oregon $R$ population.

Table 2 Comparison of the effect of 2.5 per cent Bacillus thuringiensis supernatant at $25^{\circ} \mathrm{C}$ on $\mathrm{X} / \mathrm{O}$ genotype male progeny of crosses between $\mathrm{X}$. X females and males of the $1 \mathrm{C}$ or $3 \mathrm{~B}$ lines, or those obtained from reciprocal crosses between these two lines

\begin{tabular}{|c|c|c|c|c|c|c|c|}
\hline \multirow{2}{*}{\multicolumn{2}{|c|}{ Father's genotype }} & \multicolumn{6}{|c|}{ Descendents per flask } \\
\hline & & \multicolumn{2}{|c|}{$\mathrm{X} / \mathrm{O}$ males } & \multicolumn{2}{|c|}{$\begin{array}{l}X . X / Y \\
\text { females }\end{array}$} & \multicolumn{2}{|c|}{$\begin{array}{l}\text { Male/female } \\
\text { ratio }\end{array}$} \\
\hline Autosomes & $\mathrm{X}$ chromosome & $S+$ & $S-$ & $S+$ & $S-$ & $S+$ & $S-$ \\
\hline $3 B / 3 B$ & $3 \mathrm{~B}$ & 114 & (188) & 170 & $(182)$ & 0.67 & $(1.03)$ \\
\hline $1 \mathrm{C} / 1 \mathrm{C}$ & $1 \mathrm{C}$ & 10 & $(188)$ & 167 & $(174)$ & 0.06 & $(1.08)$ \\
\hline $3 \mathrm{~B} / 1 \mathrm{C}$ & $3 \mathrm{~B}$ & 100 & $(180)$ & 179 & $(175)$ & 0.56 & (1.03) \\
\hline $3 B / 1 C$ & $1 \mathrm{C}$ & 17 & $(187)$ & 192 & $(183)$ & 0.08 & $(1.02)$ \\
\hline
\end{tabular}

$\mathrm{S}+=$ with 2.5 per cent supernatant, $\mathrm{S}-=$ without supernatant.

$\mathrm{S}+$ values are means of at least five flasks; $\mathrm{S}-$ values are means of three flasks. 


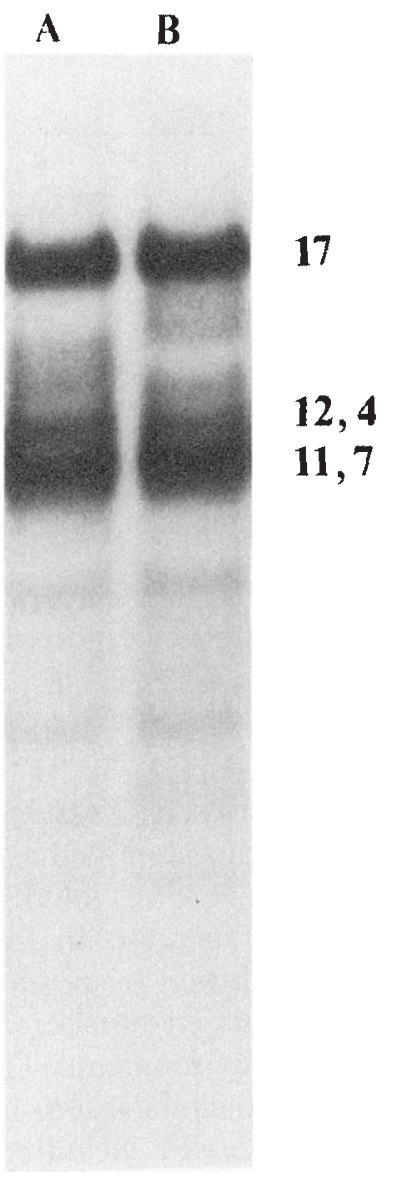

Fig. 1 EcoRIX ribosomal DNA restriction patterns in the $3 \mathrm{~B}$ and in the $1 \mathrm{C}$ Oregon $\mathrm{R}$ lines. One-quarter of the EcoRI DNA digests from 20 female larvae brains and imaginal discs for the $3 \mathrm{~B}$ line and one-quarter of the EcoRI DNA digests from 40 female larvae brains and imaginal discs for the $1 \mathrm{C}$ line were fractionated on 0.6 per cent agarose gel, blotted on to nitrocellulose and hybridized to the ${ }^{32} \mathrm{P}$-labelled $\mathrm{pDmrY}_{12}$ probe. $17,12.4$ and $11.7 \mathrm{~kb}$ are the size of the different fragments determined by reference to a DNA size marker: (the BRL ' 1 kb ladder' and $E c o$ RI digested lambda DNA). Lane $A=3 B$ line, Lane $B=1 C$ line.

Table 3, which shows the distribution of the three major fragments $(17,12.4$ and $11.7 \mathrm{~kb})$ and of the two main smaller fragments detected for the two lines. This distribution is not significantly different between the two lines. The difference between the rDNA in the 3B and $1 \mathrm{C}$ Oregon $\mathrm{R}$ lines $\mathrm{X}$ chromosomes thus concerns most of the ribosomal units (both active and inactive) as a whole: the number in the $3 \mathrm{~B}$ line is twice the number in the $1 \mathrm{C}$ line.

Some units nevertheless are represented differently in the two lines: the comparison of the two autoradio- graphs (Fig. 1) shows an interruption of the signal in the area of the 14.5-15.4 kb fragments for the $1 \mathrm{C}$ line and not for the $3 \mathrm{~B}$ line. In our experimental conditions, a similar intensity of the signal must be obtained on the autoradiographs for fragments that are twice as numerous in the $3 \mathrm{~B}$ line compared to the $1 \mathrm{C}$ line. The difference between the two patterns shows that the amount of the $14.5-15.4 \mathrm{~kb}$ fragments in the $3 \mathrm{~B}$ line is much more than twice the amount in the $1 \mathrm{C}$ line. A second difference concerns the $15-16.2 \mathrm{~kb}$ fragments: there is an interruption of the signal in the corresponding area for the $3 \mathrm{~B}$ line and not for the $1 \mathrm{C}$ one. Thus, these fragments are less than half as abundant on the $3 \mathrm{~B} X$ chromosome compared to the $1 \mathrm{C} \mathrm{X}$ chromosome.

\section{Discussion}

Our genetic results show that the differences in resistance to the lethal effect of the Bacillus thuringiensis supernatant, observed between the females of the $3 \mathrm{~B}$ Oregon $\mathrm{R}$ line derived from our variant population and the $1 \mathrm{C}$ Oregon $\mathrm{R}$ line derived from the initial stock, are related to differences in the properties of their $\mathrm{X}$ chromosomes. We have shown that twice as many ribosomal transcriptional units are present on the $3 \mathrm{~B}$ line $\mathrm{X}$ chromosome compared to that of the $1 \mathrm{C}$ line; the amount of the rDNA on this $1 \mathrm{C}$ line $\mathrm{X}$ chromosome corresponds to that usually described for the Oregon strain (Tartof, 1971, 1973a; Ritossa, 1976). The better resistance of the $3 \mathrm{~B}$ line females is thus correlated with an increase in the $\mathrm{X}$ chromosomal rDNA amount. This increase concerns the majority of the different unit types, including the uninterrupted units, which seem to be the only ones able to give an active product (Long \& Dawid, 1979; Long et al., 1980; Kidd \& Glover, 1981; Terracol \& Prud'homme, 1986; Hawley \& Marcus, 1989). These units do correspond to the $11.7-\mathrm{kb}$ EcoRI ribosomal fragments. The $17-\mathrm{kb}$ fragments represent $5 \mathrm{~kb}$ type $\mathrm{I}$ insertion interrupted units while the $12.4-\mathrm{kb}$ fragments correspond generally to $0.5-1 \mathrm{~kb}$ type I interrupted units or to uninterrupted units with a larger spacer. The fragments smaller than $10 \mathrm{~kb}$ are part of type II insertion interrupted units (Endow \& Glover, 1979; Terracol \& Prud'homme, 1986).

The two lines obtained from our Oregon R stock do not exhibit any difference in standard growth conditions. They both have a wild type phenotype. An increase in the $\mathrm{X}$ rDNA units content, particularly in the amount of active ribosomal units, has been revealed by the use of the Bacillus thuringiensis supernatant, which contains the beta-exotoxin nucleolar RNA polymerase inhibitor. 
Table 3 Distribution of the different fragments detected on the EcoRI X ribosomal DNA restriction patterns in the two lines

\begin{tabular}{|c|c|c|c|c|}
\hline \multirow{2}{*}{$\begin{array}{l}\text { Fragment } \\
\text { size } \\
(\mathrm{kb})\end{array}$} & \multicolumn{2}{|l|}{ 3B line } & \multicolumn{2}{|l|}{$1 \mathrm{C}$ line } \\
\hline & $\begin{array}{l}\text { Percentage among the total } \\
\text { X ribosomal DNA }\end{array}$ & $\begin{array}{l}\text { Number of fragments } \\
\text { per X chromosome }\end{array}$ & $\begin{array}{l}\text { Percentage of the total } \\
\text { X ribosomal DNA }\end{array}$ & $\begin{array}{l}\text { Number of fragments } \\
\text { per X chromosome }\end{array}$ \\
\hline 17 & 23.9 & 100 & 26.8 & 52 \\
\hline 12.4 & 16 & 67 & 16.2 & 32 \\
\hline 11.7 & 28.4 & 119 & 26.8 & 52 \\
\hline $\begin{array}{r}\text { Sum of the two main } \\
\text { smaller fragments }\end{array}$ & 6.2 & 26 & 8.2 & 16 \\
\hline
\end{tabular}

The percentage of each fragment among the total X ribosomal DNA was determined by integration of the areas of the peaks obtained on densitometric scanning of the autoradiographs.

The number of fragments per $\mathrm{X}$ chromosome was calculated taking account of the average number of the $\mathrm{X}$ ribosomal units: 418 for the $3 \mathrm{~B}$ line and 195 for the $1 \mathrm{C}$ line. The $\chi^{2}$ calculated with these results shows that the ratios of the different fragments in the two lines is not significantly different.

Ribosomal DNA evolution has previously been studied with 'bobbed' mutants because of the possibility of following variations in the amount of functional rDNA by variation in the intensity of the 'bobbed' phenotype, particularly in the case of the magnification phenomenon (Ritossa, 1972; Locker \& Prud'homme, 1973; Tartof, 1973b; Terracol \& Prud'homme, 1986; Terracol, 1987). However this method needs particular crosses and genotypes with a very low level of active ribosomal units (Tartof, 1974; Hawley \& Tartof, 1985; Marcus et al., 1986) and cannot be used to follow variations in the rDNA amount in wild type flies. The method we describe here, however, could be used to follow such variations among a wild type population.

The $3 \mathrm{~B}$ line was isolated from a variant Oregon $\mathrm{R}$ population selected at high temperature. We had previously observed a correlation between the sensitivity of different genotypes to the lethal effect of the increase in temperature and to that of the Bacillus thuringiensis supernatant (Paumard-Rigal \& Rosenberg-Bourgin, 1990). The 3B line females have more active ribosomal transcriptional units compared to the $1 \mathrm{C}$ line females. Thus, the increase in the number of the active ribosomal transcriptional units could have given a selective advantage expressed when the developmental temperature had increased too much: the development time being shorter at $28^{\circ} \mathrm{C}$ than at $25^{\circ} \mathrm{C}$; a higher rate of synthesis, including that of the rRNA, may be necessary at $28^{\circ} \mathrm{C}$. In the $3 \mathrm{~B}$ line compared to the $1 \mathrm{C}$ line; the different main unit types: interrupted and uninterrupted have been increased in the same proportion. This suggests that this increase could result from a single molecular event, for example, an unequal exchange which would have transferred the main part of the rDNA from one chromatid to another, generating simultaneously a large deletion in the rDNA, similar to deletions identified in lethal 'bobbed' mutations (Ritossa et al., 1966). Could such a mechanism: the simultaneous increase in interrupted and uninterrupted units, followed by positive selection of genotypes with an increased number of active units, occur in the natural environment? This could then have contributed to maintaining inserts in the rDNA, in addition to other processes including the possible transposition of the DNA insertions that have been identified as retrotransposable elements (Jakubczach et al., 1990).

The mechanism postulated to explain the twofold increase in the number of most units on the $3 B$ line $X$ chromosome cannot, however, explain all the differences observed between the $\mathrm{X}$ rDNA of our two lines. The number of the 14.5-15.4 kb fragments in the 3B line is more than twice that in the $1 \mathrm{C}$ line. Two hypotheses could explain this observation: either the corresponding unit type had been amplified in the $3 \mathrm{~B}$ line or these units had been eliminated from the $1 \mathrm{C} \mathrm{X}$ chromosome. One of the mechanisms of this elimination could be unequal recombination. The same unit types are clustered in the rDNA locus (Appels \& Hilliker, 1982; Sharp et al., 1983; Salzano \& Malva, 1984; Terracol \& Prud'homme, 1986; Gillings et al., 1987; Terracol, 1987; England et al., 1988) and can be eliminated together during such an event. The observation is inverted for the $15-16.2 \mathrm{~kb}$ fragments, which are more represented on the $1 \mathrm{C}$ line $\mathrm{X}$ chromosome: they had been either eliminated from the $3 B$ line $X$ chromosome or amplified in the $1 \mathrm{C}$ line $\mathrm{X}$ chromosome. Thus, there is more than one modification of the rDNA between the two lines. Heterogeneity of our initial Oregon $R$ population had been observed in 
temperature-resistant tests on individual $\mathrm{X} / \mathrm{O}$ genotypes (Paumard-Rigal \& Rosenberg-Bourgin, 1990). This could be related to differences in the rDNA content and could thus reveal frequent variations in the rDNA locus. In non-selective conditions they do not lead to any modification of the global population characteristics and thus should be essentially reciprocal modifications probably resulting from unequal recombinations.

\section{References}

APPELS, R. AND HILlikeR, A. J. 1982. The cytogenetic boundaries of the rDNA region within heterochromatin of the $\mathrm{X}$ chromosome of Drosophila melanogaster and their relation to male meiotic pairing site. Genet. Res. Camb., 39, 149-156.

BEEBEE, T. J. C. AND BOND, R. P. M. 1973. Effect of the exotoxin of Bacillus thuringiensis on normal and ecdysone stimulated ribonucleic acid polymerase activity in intact nuclei from the fat-body of Sarcophaga bullata larvae. Biochem. J., 136, 1-7.

BIRNBOIM, H. C. AND DOLY, J. 1979. A rapid alkaline extraction procedure for screening recombinant plasmid DNA. Nucl. Acid. Res., 7, 1513-1523.

COOPER, K. W. 1959. Cytogenetic analysis of major heterochromatic elements (especially $\mathrm{Xh}$ and $\mathrm{Y}$ ) in Drosophila melanogaster and the theory of 'heterochromatin'. Chromosoma, 10, 535-588.

DUTTON, F. L. AND KRIDER, M. M. 1984. Ribosomal RNA cistrons of X chromosomes clonally derived from $D$. melanogaster laboratory populations: redundancy, organization and stability. Genetics, 107, 405-421.

ENDOW, S. A. AND GLOVER, D. M 1979. Differential replication of ribosomal repeats in polytene nuclei of Drosophila. Cell, 17, 597-605.

ENGLAND, P. R., STOKES, H. W. AND FANKHAM, R. 1988. Clustering of rDNA containing type 1 insertion sequence in the distal nucleolus organizer of Drosophila melanogaster: implications for the coevolution of X and Y rDNA arrays. Genet. Res. Camb., 51, 209-215.

EPHRUSSI, B. AND BEADLE, G. v. 1936. A technique of transplantation for Drosophila. Am. Nat., 70, 218-225.

GILLINGS, M. R., FRANKHAM, R., SPEIRS, J. AND WHALLEY, M. 1987. $\mathrm{X}-\mathrm{Y}$ exchange and the coevolution of the $\mathrm{X}$ and $\mathrm{Y}$ rDNA arrays in Drosophila melanogaster. Genetics, 116, 241-251.

HAWLEY, R. S. AND MARCUS, C. H. 1989. Recombinational controls of rDNA redundancy in Drosophila. Ann. Rev. Genet., 23, 87-120.

HAWLEY, R. S. AND TARTOF, K. D. 1985. A two-stage model for the control of rDNA magnification. Genetics, 109, 691-700.

JAKUBCZACK, J. L., XIONG, Y. AND EICKBUSH, H. 1990. Type I (R1) and type II (R2) ribosomal DNA insertions of Drosophila melanogaster are retrotransposable elements closely related to those of Bombyx mori. J. Mol. Biol., 212, $37-52$.
KIDD, S. J. AND GLover, D. M. 1981. Drosophila melanogaster ribosomal DNA containing type II insertions is variably transcribed in different strains and tissues. J. Mol. Biol., 151, 645-662.

LECADET, M. M. AND DEDONDER, R. 1971. Biogenesis of the crystalline inclusion of Bacillus thuringiensis during sporulation. Eur. J. Biochem., 23, 282-294.

LINDSLEY, D. L. AND GRELL, E. H. 1968. Genetics variations of Drosophila melanogaster. Carnegie Institute of Washington Publication. 627.

LOCKER, D. AND PRUD'HOMmE, N. 1973. Etude de plusieurs facteurs faisant varier la fréquence de réversion au locus bobbed chez Drosophila melanogaster. Mol. Gen. Genet., $124,1119$.

LONG, E. O. AND DAWID. I. B. 1979. Expression of ribosomal DNA insertions in Drosophila melanogaster. Cell, 18, 1185-1196.

LONG, E. O. AND DAWID, I. B. 1980. Repeated genes in Eucaryotes. Ann. Rev. Biochem., 49, 727-764.

LONG, E. O., REBBERT, M. L. AND DAWID, I. B. 1980. Structure and expression of ribosomal RNA genes of Drosophila melanogaster interrupted by type 2 insertions. Cold Spring Harbor Symp. Quant. Biol., 45, 667-672.

MCCONNEL, E. AND RICHARDS, A. G. 1959. The production by Bacillus thuringiensis Berliner of a heat-stable substance toxic for insects. Can. J. Microbiol., 5, 161-168.

MACKEDONSKI, v. V., HADJIOLOV, A. A. AND SEBESTA, K. 1972. Preferential in vivo inhibition of ribosomal ribonucleic acid synthesis in mouse liver by exotoxin of Bacillus thuringiensis. FEBS Lett., 21, 211-214.

MARCUS, C. H., ZITRON, A. E., WRIGHT, D. A. AND HAWLEY, R. S. 1986. Autosomal modifiers of the bobbed phenotype are a major component of the rDNA magnification paradox in Drosophila melanogaster. Genetics, 113, 305-319.

PAUMARD, S. AND BOURGIN-ROSENBERG, M. 1981. Utilisation du surnageant de cultures de Bacillus thuringiensis dans une étude in vivo du fonctionnement de l'organisateur nucléolaire chez Drosophila melanogaster. C. R. Acad. Sci. Paris, 293, 257-260.

PAUMARD-RIGAL, S. AND ROSENBERG-BOURGin, M. 1990. High temperature of development and selection of Bacillus thuringiensis supernatant-resistant females in a Drosophila melanogaster Oregon R strain. Genetica, 81, 215-228.

PEACOCK, W. J., APPELS, R., ENDOW, S. AND GLOVER, D. 1981. Chromosomal distribution of the major insert in Drosophila melanogaster $28 \mathrm{~S}$ rRNA genes. Genet. Res. Camb., 37, 209-214.

RITOSSA, F. M. 1972. Procedure for magnification of lethal deletions of genes for ribosomal RNA. Nature New. biol., 240, 109-111.

RITOSSA, F. 1976. The bobbed locus. In: Genetics and Biology of Drosophila Vol. 1b: Ashburner, M. and Novitski, E. (eds) Academic Press, London, pp. 801-846.

Ritossa, F. M., ATwood, K. C. AND SPIEgelman, S. 1966. A molecular explanation of the bobbed mutants of Drosophila as partial deficiencies of "ribosomal" DNA. Genetics, 54, 819-834.

RITOSSA, F. M. AND SPIEGELMAN, S. 1965. Localization of DNA complementary to ribosomal RNA in the nucleolus 
organizer region of Drosophila melanogaster. Proc. Natl. Acad. Sci., U.S.A., 53, 737-745.

ROIHA, H., MILleR, J. R., WoOdS, L. C. AND GLoVER, D. M. 1981. Arrangements and rearrangements of sequences flanking the two types of rDNA insertions in Drosophila melanogaster. Nature, 290, 749-753.

ROSENBERG-BOURGIN, M., PAUMARD, S. AND CONTESSE, G. 1988a. Comparative study of molecular characteristics of $\mathrm{X}$ and Y nucleolar organizers of various lines of Drosophila melanogaster. Biol. Cell, 62, 201-209.

ROSENBERG-BOURGIN, M., PAUMARD, S., BRACONE, A. AND CONTESSE, G. 1988b. Comparison between the molecular characteristics and the potential activity of $\mathrm{X}$ and $\mathrm{Y}$ nucleolar organizers from various Drosophila melanogaster laboratory lines. Biol. Cell, 64, 3-11.

SALZANO, G. AND MALVA, C. 1984. Non-random loss of uninterrupted ribosomal DNA repeating units upon induction of bobbed mutation. J. Mol. Biol., 177, 189-200.

SHARP, Z. D., GHANDI, V. V. AND PROCUNIER, J. D. 1983. X chromosome nucleolus organiser mutants which alter major type I repeat multiplicity in Drosophila melanogaster. Mol. Gen. Genet., 190, 438-443.

SPEAR, B. B. 1974. The genes for ribosomal RNA in diploid and polytene chromosomes of Drosophila melanogaster. Chromosoma, 48, 159-179.

TARTOF, K. D. 1971. Increasing the multiplicity of ribosomal RNA genes in Drosophila melanogaster. Science, 171, 294-297.
TARTOF, K. D. 1973a. Regulation of ribosomal RNA gene multiplicity in Drosophila melanogaster. Genetics, 73, 57-71.

TARTOF, K. D. 1973b. Unequal sister chromatid exchange and disproportionate replication as mechanisms regulating ribosomal RNA gene redundancy. Cold Spring Harbor Symp. Quant. Biol., 38, 491-500.

TARTOF, K. D. 1974. Unequal mitotic sister chromatid exchange as the mechanism of ribosomal gene magnification. Proc. Natl. Acad. Sci., U.S.A., 71, 1272-1276.

TARTOF, K. D., AND DAWID, T. B. 1976. Similarities and differences in the structure of $\mathrm{X}$ and $\mathrm{Y}$ chromosomes rRNA genes of Drosophila. Nature, 263, 27-30.

TERRACOL, R. 1987. Differential magnification of rDNA gene types in bobbed mutants of Drosophila melanogaster. Mol. Gene Genet., 208, 168-176.

TERRACOL, R. AND PRUD'HOMME, N. 1986. Differential elimination of rDNA genes in bobbed mutants of Drosophila melanogaster. Mol. Cell. Biol., 6, 1023-1031.

WAHL, G. M., STERN, M. AND STARK, G. R. 1979. Efficient transfer of large DNA fragments from agarose gels to diazobenzyloxymethyl-paper and rapid hybridization by using dextran sulfate. Proc. Natl. Acad. Sci., U.S.A., 76, 3683-3687.

WELlAUER, P. K., DAWID, I. B. AND TARTOF, K. D. 1978. X and Y chromosomal ribosomal DNA of Drosophila melanogaster: Comparison of spacers and insertions. Cell., 14, 269-278. 